\title{
Life cycle and parasitic competence of Dermacentor nitens Neumann, 1897 (Acari: Ixodidae) on different animal species
}

\author{
Vinicius da Silva Rodrigues ${ }^{\mathrm{a}}$, Marcos Valério Garcia ${ }^{\mathrm{b}}$, Breno Cayeiro Cruz ${ }^{\mathrm{c}}$, \\ Willian Giquelin Maciel ${ }^{\mathrm{c}}$, Namor Pinheiro Zimmermann ${ }^{\mathrm{d}}$, Wilson Werner Koller ${ }^{\mathrm{e}}$, \\ Jacqueline Cavalcante Barros ${ }^{\mathrm{e}}$, Renato Andreotti ${ }^{\mathrm{e}, *}$ \\ a Pós-Graduação em Doenças Infecciosas e Parasitárias-Faculdade de Medicina, UFMS-Univ. Federal Mato Grosso do Sul, Laboratório de Biologia do \\ Carrapato, Embrapa Gado de Corte, Campo Grande, MS, Brazil \\ ${ }^{\mathrm{b}}$ Laboratório de Biologia do Carrapato, Empresa Brasileira de Pesquisa Agropecuária, Embrapa Gado de Corte, Bolsista DCR Fundect, MS-Governo do \\ estado de Mato Grosso do Sul, Campo Grande, MS, Brazil \\ c Faculdade de Ciências Agrárias e Veterinárias, UNESP-Univ. Estadual Paulista, Campus de Jaboticabal, Departamento de Patologia Veterinária, \\ CPPAR-Centro de Pesquisas em Sanidade Animal, Brazil \\ ${ }^{\mathrm{d}}$ Laboratório de Biologia do Carrapato, Empresa Brasileira de Pesquisa Agropecuária, Embrapa Gado de Corte, Campo Grande, MS, Brazil \\ e Empresa Brasileira de Pesquisa Agropecuária, Embrapa Gado de Corte, Campo Grande, MS, Brazil
}

\section{A R T I C L E I N F O}

\section{Article history:}

Received 7 October 2016

Received in revised form

29 December 2016

Accepted 29 December 2016

Available online 31 December 2016

\section{Keywords:}

Hosts

Tick

Artificial infestation

Dermacentor nitens

\begin{abstract}
A B S T R A C T
The objective of this study was to evaluate the life cycle and parasitic competence of Dermacentor nitens (Neumann, 1897) on different animal species. Experimental infestations were induced in five specimens each of seven species of possible hosts: rabbits, horses, sheep, cows, guinea pigs, birds and dogs. Rabbits were infested in the ear using artificial feeding chambers, and the horses, sheep, cows and dogs were infested in the ear without feeding chambers. For the infestation of guinea pigs, artificial feeding chambers were fixed on the back. Birds were infested by placing larvae on the back and under the wings without the use of chambers. All animals were inspected daily until the end of the parasitic phase (when the engorged females detached). The average period of engorgement was 25.1 days on a horse, with larvae requiring 8 days and nymphs 9 days to reach engorgement; the average weight of engorged females was $271.4 \mathrm{mg}$; the average weight of egg batches produced was $159.3 \mathrm{mg}$, and the feed conversion rate was $56.8 \%$. On rabbits, the average engorgement period was 27.6 days, larvae and nymphs reached engorgement after 7.4 and 11 days, respectively, the average weight of an engorged female was $108.4 \mathrm{mg}$ and the egg mass was $30.6 \mathrm{mg}$. The feed conversion rate on rabbits was $30 \%$. Cows, sheep, guinea pigs, dogs and birds were not competent hosts, since no engorged females were recovered. Rabbits, when artificially infested, can be used as an alternative host for the maintenance of these ticks in the laboratory. The parasitic specificity of $D$. nitens for horses was demonstrated in this study.
\end{abstract}

(c) 2016 Elsevier GmbH. All rights reserved.

\section{Introduction}

The tick Dermacentor nitens is widely distributed within the Brazilian territory and is an important ectoparasite that affects animal health by transmitting Babesia caballi among equines, which

\footnotetext{
* Corresponding author at: Empresa Brasileira de Pesquisa Agropecuária, Embrapa Gado de Corte, Avenida Rádio Maia, 830, Campo Grande, MS, CEP 79106 550, Brazil. E-mail addresses: vinicius_srod@hotmail.com (V.d.S. Rodrigues), marcosvagar@gmail.com (M.V. Garcia),breno.c.cruz@hotmail.com (B.C.Cruz), willian.vet@hotmail.com (W.G. Maciel), namorvet@gmail.com (N.P.Zimmermann), wilson.koller@embrapa.br (W.W. Koller), jacqueline.barros@embrapa.br (J.C. Barros), renato.andreotti@embrapa.br (R. Andreotti).
}

causes equine babesiosis (Roby and Anthony, 1963). The vector capacity of $D$. nitens for pathogens related to public health remains unknown; however, agents pathogenic to humans have been previously detected (Bermudez et al., 2009; Gonçalves et al., 2013).

Of the tick species that parasitize equines, $D$. nitens is the most common, and high infestations may promote a reduction below the minimum normal reference of red blood cells of these animals, increasing their susceptibility to diseases (Labruna et al., 2002). D. nitens is a one-host tick, with equines as the primary host, having a preference for infesting ears, perineum, nasal diverticulum and the mane (Labruna et al., 2002; Borges and Leite, 1993; Borges et al., 2000). High infestations may cause lesions on ears, resulting in permanent cartilage damage, in addition to creating favorable 
conditions for myiasis and the initiation of secondary infections (Labruna and Amaku, 2006).

In the southeast region of Brazil, $D$. nitens has 3-4 generations annually (Borges et al., 2000; Labruna et al., 2002). According to Labruna et al. (2002), the highest peaks of tick infestation occur in the first semester of the year, followed by a drastic reduction that occurs in August, with a new peak in September and October.

Although equines are the primary host, natural infestations are reported in other domestic and wild animals (Borges and Silva, 1994; Ferreira et al., 2009; Martins et al., 2015; Rocha, 1985), and under experimental conditions, rabbits, guinea pigs and bovines have been infested (Drummond et al., 1969; Serra Freire and Miziara, 1989).

To study tick biology and ecology, their parasite-host interactions, and the relation with pathogens they transmit, the importance of maintaining colonies of these ectoparasites in controlled conditions cannot be disputed. However, the maintenance of natural hosts may be expensive or difficult for operational reasons (Bonnet and Liu, 2012); therefore, the use of alternative hosts, which are easily handled, is both useful and practical.

To improve the understanding of the differences among populations, it is necessary to determine the occurrence, biology and ecology of this tick species in different geographical regions. In this study, the objective was to evaluate the parasitic competence of $D$. nitens on different hosts under experimental conditions.

\section{Materials and methods}

\subsection{Study location}

The study was performed on the Embrapa Gado de Corte Experimental Farm at the following geographical location: lat $20^{\circ} 25^{\prime} 03^{\prime \prime}$ S, long 54 42'20' W; Animal Health sector, municipality of Campo Grande, state of Mato Grosso do Sul, in the center-west region of Brazil.

\subsection{Animal use}

The Ethics Commission on the Use of Animals/CEUA of the Federal University of Mato Grosso do Sul/UFMS, under protocol number 699/2015, approved this study. In this study, five specimens were used for each host species, which were rabbits, horses, sheep, cows, guinea pigs, chickens and dogs. For infestation of horses, bovines and sheep, 1000 larvae were used in each animal; 300 larvae were used for the other hosts. For infestation we used plastic syringes adapted as described by Labruna and Amaku (2006).

\subsection{Ticks used for infestation}

Unfed $D$. nitens larvae used for infestations were obtained from engorged females collected from naturally infested horses in the region of the study. Engorged females were maintained in B.O.D. incubators at $28^{\circ} \mathrm{C}\left(82.4^{\circ} \mathrm{F}\right)$ and $80 \%$ humidity for posture, incubation and larval hatching. All larvae used in experimental infestations were between 20 and 30 days in age (Fig. $1 \mathrm{H}$ ), according to the recommendation of Labruna and Amaku (2006).

\subsection{Experimental infestation in rabbits}

Rabbits (Oryctolagus cuniculus) of the New Zealand breed, with no previous tick contact and without distinction of gender, were maintained in individual cages and supplied with a balanced ration and water ad libitum. Their ears were infested with the aid of artificial tick feeding chambers made with fabric and adhered to the base of the ears. The chambers were fixed with atoxic glue, according to modified techniques of Oliveira et al. (1974) and Szabó et al. (1995).

\subsection{Experimental infestation on equines}

Adult horses (Equus caballus) without a defined breed were kept in paddocks with Cynodon spp. pasture, ad libitum water and a balanced ration provided twice a day. During the infestation and evaluation procedures, animals were manually restrained, with the aid of halter. The ear and perineal region were infested without the use of feeding chambers.

\subsection{Experimental infestation on ovines}

Sheep (Ovis aries) were kept in individual stalls and fed with a balanced ration and with ad libitum access to water. Only females from the Santa Inês breed were used. The ears of the animals and the perineum area were infested without the use of feeding chambers, as described for equines.

\subsection{Experimental infestation on bovines}

Angus heifers (Bos taurus) were used. For the infestations, animals were kept in individual stalls, fed with a balanced ration and given water ad libitum. These heifers were manually restrained with halter and the ears were infested without the aid of artificial feeding chambers.

\subsection{Experimental infestation on guinea pigs}

Guinea pigs (Cavia porcellus) were kept in individual cages, fed with a balanced ration and given water ad libitum. Only animals without previous contact with ticks, of both sexes, were used. The infestation process used artificial feeding chambers fixed on the backs of the animals, as previously described.

\subsection{Experimental infestation on birds}

Domestic chickens (Gallus gallus), were kept in individual cages, fed with a balanced ration and given water ad libitum. Animals without distinction of gender and without previous contact with ticks were used. The animals' backs and the region under their wings were infested, without the use of feeding chambers.

\subsection{Experimental infestation on dogs}

Adult dogs (Canis familiaris), with no defined breed and without distinction of gender, were selected and kept in individual kennels, fed with adequate rations and given water ad libitum. The ears were infested without the use of feeding chambers.

\subsection{Monitoring biological parameters of ticks}

Artificially infested animals were monitored daily. The duration of the entire parasitic phase was observed with evaluations of the larval parasitic period, nymphal parasitic period and female parasitic period.

To evaluate the tick's nonparasitic phase in laboratory conditions, after complete engorgement, detached females were collected, individually weighed and then maintained in a B.O.D. incubator chamber at $28^{\circ} \mathrm{C}$ and $80 \%$ humidity.

The following biological parameters were evaluated, according to Szabó et al. (1995): engorged female weight; pre-oviposition 

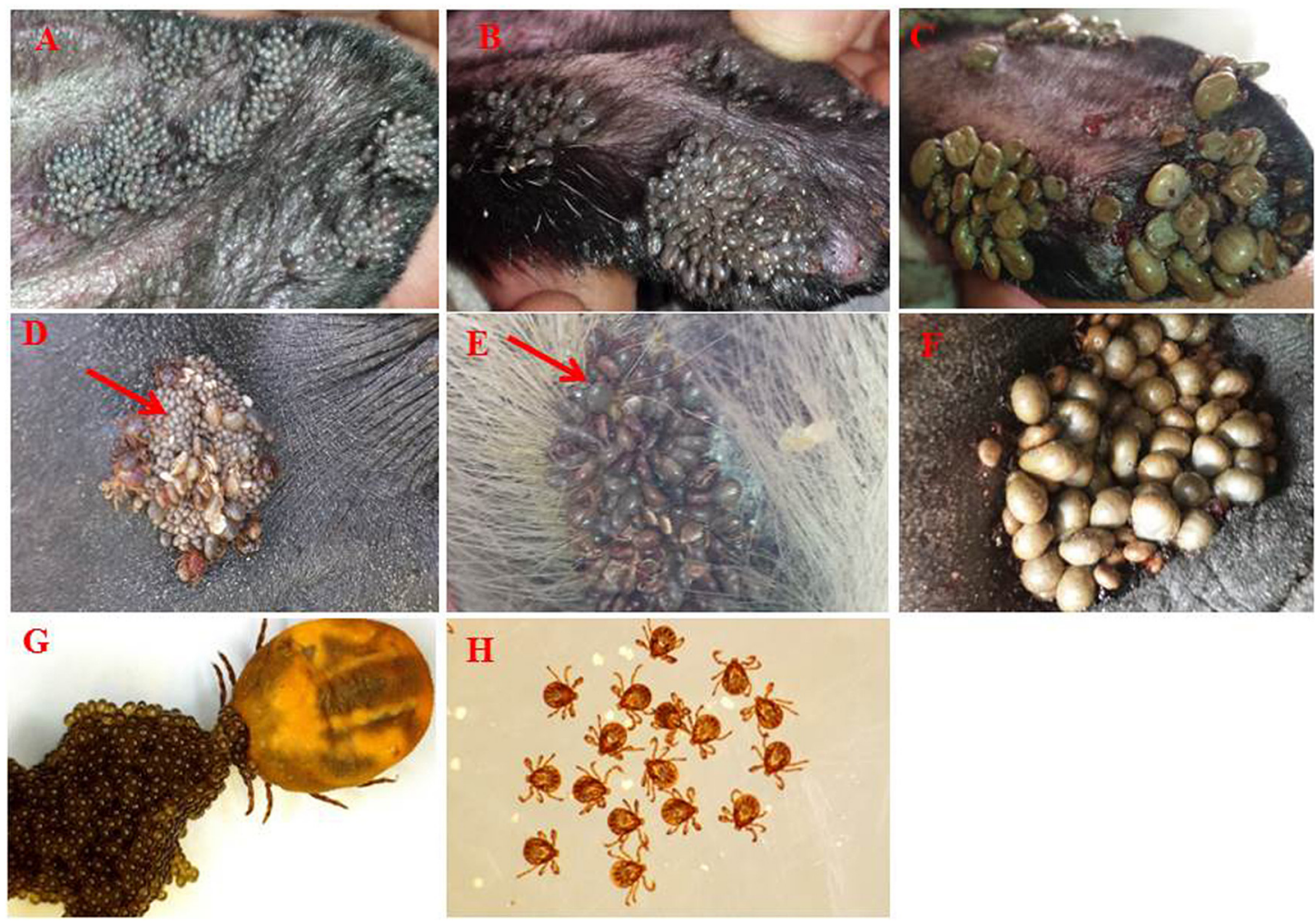

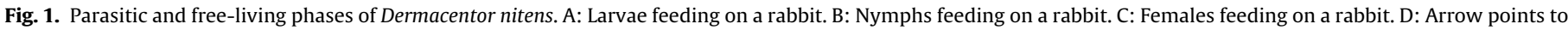

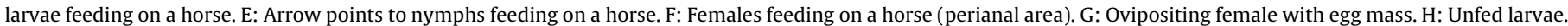

period; egg mass weight; egg mass conversion ratio; incubation period; and larval hatching rate.

\subsection{Quantitative determination of eggs produced}

To quantify the number of eggs, 28 engorged females were collected from horses and were kept individually in vials for egg laying that were maintained in a B.O.D. incubator at $28^{\circ} \mathrm{C}$ and $80 \%$ relative humidity. Fifteen days after oviposition, egg masses were weighed individually on an analytical scale and all eggs were counted. A glycerin and alcohol solution was used to separate the eggs, and eggs were counted in Petri dishes with the use of a stereomicroscope, tweezers and stylets. To determine the quantity of eggs per gram of mass, the following formula was used:

Eggs per gram=number of eggs/egg mass weight in milligrams $\times 1000$

\subsection{Data analyses}

The statistical software package IBM SPSS Statistics version 20 was used to evaluate the biological parameters in this study. For descriptive statistical analyses, the $U$ test of Mann-Whitney was used, with variables considered significant when $\mathrm{p}<0.05$.

\section{Results}

\subsection{Experimental infestation on equines}

In the parasitic phase of $D$. nitens on horses, the average larval parasitic period, which includes engorgement and premolt periods, was eight days (Fig. 1D), the average nymphal parasitic period which includes engorgement and premolt periods, was nine days (Fig. 1E), and the engorgement of females until detachment was 8.1 days (Fig. $1 \mathrm{~F}$ ); therefore, the parasitic phase was completed in
25.1 days (Table 1 ). The average weight of an engorged female was $271.4 \mathrm{mg}$, with maximum and minimum values of $427.2 \mathrm{mg}$ and $105.4 \mathrm{mg}$, respectively. For the pre-oviposition period, the average was 4.6 days. The average egg mass weight was $159.3 \mathrm{mg}$ (Fig. 1G), with a total feed conversation rate of $56.8 \%$. The average incubation period was 25.7 days, and the hatching rate was $95.5 \%$ (Table 2 ). Based on these results, the average $D$. nitens life cycle was 55.4 days.

\subsection{Experimental infestation on rabbits}

Using rabbits as hosts, the average larval parasitic period, which includes engorgement and premolt periods, was 7.4 days (Fig. 1A), the average nymphal parasitic period, which includes engorgement and premolt periods, was 11 days (Fig. 1B), and the period of female engorgement until detachment was 9.2 days (Fig. 1C). Therefore, the parasitic phase was completed in 27.6 days (Table 1 ). The average engorged female weight was $108.4 \mathrm{mg}$, and the maximum and minimum values were $200 \mathrm{mg}$ and $69.9 \mathrm{mg}$, respectively. The preoviposition period was 4.2 days. The average egg mass weight was $30.6 \mathrm{mg}$, resulting in a feed conversion rate of $30 \%$. The average incubation period was 30.7 days, and the hatching rate was $96 \%$ (Table 2). The average $D$. nitens life cycle, when parasitizing rabbits, was 62.5 days.

\subsection{Experimental infestation on other host species}

The infestation of $D$. nitens on guinea pigs was unsuccessful because no engorged females were recovered. Two guinea pigs had larvae attach, which remained attached for eleven days, however, after this observation, the ticks naturally detached (Table 1 ).

As with guinea pigs, cows were not competent hosts for $D$. nitens. Larvae attached to the ear of only one bovine and those remained attached for only seven days before detaching, similar to tick behavior with guinea pigs (Table 1 ). 
Table 1

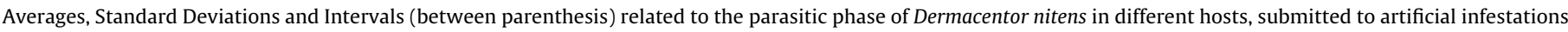
in Campo Grande, MS, Brazil. Values on the same column, followed by different letters, are significantly different $(\mathrm{p}<0.05)$

\begin{tabular}{|c|c|c|c|c|}
\hline \multirow[t]{2}{*}{ Host species } & \multicolumn{4}{|c|}{ Length, in days, for each period of the parasitic phase of $D$. nitens } \\
\hline & $\begin{array}{l}\text { Larval parasitic } \\
\text { period }\end{array}$ & $\begin{array}{l}\text { Nymphal parasitic } \\
\text { period }\end{array}$ & $\begin{array}{l}\text { Female parasitic } \\
\text { period }\end{array}$ & Parasitic phase \\
\hline Equus caballus & $\begin{array}{l}8.0 \pm 0.57 \\
(7.0-9.0)\end{array}$ & $\begin{array}{l}9.0 \pm 0.57^{a} \\
(8.0-10.0)\end{array}$ & $\begin{array}{l}8.1 \pm 0.37 \\
(8.0-9.0)\end{array}$ & $\begin{array}{l}25.1^{\mathrm{a}} \pm 0.37 \\
(25.0-26.0)\end{array}$ \\
\hline Oryctolagus cuniculus & $\begin{array}{l}7.4 \pm 0.54 \\
(7.0-8.0)\end{array}$ & $\begin{array}{l}11.0 \pm 0.7^{b} \\
(10.0-12.0)\end{array}$ & $\begin{array}{l}9.2 \pm 1.92 \\
(7.0-12.0)\end{array}$ & $\begin{array}{l}27.6^{\mathrm{b}} \pm 1.34 \\
(27.0-30.0)\end{array}$ \\
\hline Cavia porcellus & $11.0^{*}$ & - & - & - \\
\hline Bos taurus & $7.0^{* *}$ & - & - & - \\
\hline
\end{tabular}

-Values were not obtained.

* It was possible to observe larvae engorgement in only one animal.

** Larvae remained fixed during the period, however did not engorge.

Table 2

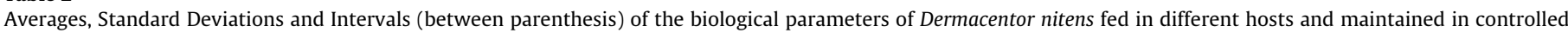
conditions of temperature $\left(28^{\circ} \mathrm{C}\right)$ and humidity $(80 \%)$. Values on the same column, followed by different letters, are significantly different ( $\left.\mathrm{p}<0.05\right)$.

\begin{tabular}{|c|c|c|c|c|c|c|}
\hline Host Species & $\begin{array}{l}\text { Engorged female } \\
\text { weight (mg) }\end{array}$ & $\begin{array}{l}\text { Pre-oviposition } \\
\text { period (days) }\end{array}$ & $\begin{array}{l}\text { Egg mass weight } \\
(\mathrm{mg})\end{array}$ & $\begin{array}{l}\text { Feed conversion } \\
\text { ratio }(\%)\end{array}$ & $\begin{array}{l}\text { Incubation period } \\
\text { (days) }\end{array}$ & $\begin{array}{l}\text { Larvae hatching } \\
\text { rate (\%) }\end{array}$ \\
\hline Equus caballus & $\begin{array}{l}271.4^{\mathrm{a}} \pm 66.1 \\
(105.4-427.2)\end{array}$ & $\begin{array}{l}4.6^{\mathrm{a}} \pm 0.5 \\
(3.0-6.0)\end{array}$ & $\begin{array}{l}159.3^{\mathrm{a}} \pm 45.9 \\
(41.0-267.0)\end{array}$ & $\begin{array}{l}56.8^{\mathrm{a}} \pm 5.9 \\
(36.0-65.0)\end{array}$ & $\begin{array}{l}25.7^{\mathrm{a}} \pm 1.3 \\
(21.0-28.0)\end{array}$ & $\begin{array}{l}95.5^{\mathrm{a}} \pm 7.9 \\
(50.0-100.0)\end{array}$ \\
\hline Oryctolagus cuniculus & $\begin{array}{l}108.4^{\mathrm{b}} \pm 33.3 \\
(69.9-200.0)\end{array}$ & $\begin{array}{l}4.2^{\mathrm{b}} \pm 0.8 \\
(2.0-6.0)\end{array}$ & $\begin{array}{l}30.6^{b} \pm 11.2 \\
(13.0-66.0)\end{array}$ & $\begin{array}{l}30.0^{\mathrm{b}} \pm 10.8 \\
(7.0-48.0)\end{array}$ & $\begin{array}{l}30.7^{\mathrm{b}} \pm 1.8 \\
(28.0-39.0)\end{array}$ & $\begin{array}{l}96.0^{\mathrm{b}} \pm 16.2 \\
(10.0-99.0)\end{array}$ \\
\hline
\end{tabular}

Infestations of $D$. nitens on birds, dogs and sheep were not successful, and no attached larvae was observed in the infestation location or elsewhere on the bodies of these animals. Therefore, for this tick species, birds, dogs, and sheep were not competent hosts.

\subsection{Quantitative determination of egg number in masses}

The average count was 18,422.4 eggs per gram of egg mass, with maximum and minimum values of $21,761.1$ and $16,639.1$, respectively (Table 3 ).

\section{Discussion}

Most data regarding the biology and ecology of this tick in Brazil are at least a decade old, based on studies performed in the southeast region of the country (Borges et al., 1999, 2000, 2002; Labruna et al., 2001, 2002; Labruna and Amaku, 2006; Sanavria and Prata, 1996). However, because of these limitations, the specific characteristics of geographically distinct populations, such as those in the center-west region of the country, must also be investigated. Additionally, the currently available information may require updating because of climate changes in recent years, which can alter the biological and ecological behavior of the ectoparasite.

Sanavria and Prata (1996) examined the parasitic phase of this ectoparasite's life cycle on equines in the southeast region of Brazil and obtained similar results to those found in this study. The exceptions were the length of time required for female engorgement, which was 10 days in their study compared with 8.1 days in this study, and the parasitic phase of $D$. nitens, which was 28 days in their study compared with only 25.1 days in this study. The results found in this study for rabbits were similar to those obtained by Sanavria and Prata (1996), most likely because rabbits are not preferential hosts.

The length of the parasitic phase determined in this study was consistent with the data of Labruna and Amaku (2006), who found that detachment occurs between 25 and 27 days in an evaluation of the detachment rhythm of $D$. nitens engorged females on equines. The results obtained by Drummond et al. (1969) are also similar, with an engorgement period of 25.4 days.
Average weights of engorged females and egg masses observed by Sanavria and Prata (1996) are less than the values obtained in this study. These authors observed an average weight of $200.1 \mathrm{mg}$ for an individual engorged female and $87 \mathrm{mg}$ for the average weight of deposited egg masses. These values are less than those observed in this study, which were $271.4 \mathrm{mg}$ for engorged females and $159.3 \mathrm{mg}$ for egg masses. Labruna and Amaku (2006) described weights for engorged females that vary from $276.5 \mathrm{mg}$ to $359.5 \mathrm{mg}$ and from $147 \mathrm{mg}$ and $171.3 \mathrm{mg}$ for egg masses, according to the conditions in which their study was performed. To justify these differences in engorged female and egg mass weights among studies, a reasonable hypothesis would be that each study was performed under different conditions. A number of studies report significant differences in the biological parameters of ticks when exposed in field and laboratory conditions (Yu et al., 2010; Meng et al., 2014; Nava et al., 2011; Tarragona et al., 2015). The studied parameters of the non-parasitic phase of the present research cannot be extrapolated to the field.

The feed to eggs conversion ratio of engorged females collected from equines in this study (58.6\%) was consistent with the values (40.6\%-57.1\%) obtained by Labruna and Amaku (2006). In a similar study, Sanavria and Prata (1996) obtained a different result (43.5\%), and in another study, the reproductive efficiency was of 46.3\% (Borges, 1991). Guimarães da Silva et al. (1997) evaluated the feed conversion rate of $D$. nitens maintained at $26^{\circ} \mathrm{C}$, with different conditions of humidity, and the reproductive efficiency rate was $56.3 \%$ at a relative humidity of $95 \%$, but only $44.7 \%$ at an index of $70 \%$ relative humidity. In a study in which temperature was evaluated, the conversion rate was $35.6 \%$ at $18{ }^{\circ} \mathrm{C}$, whereas at temperatures of $27^{\circ} \mathrm{C}$ and $32{ }^{\circ} \mathrm{C}$, the conversion rates were $48.5 \%$ and $49 \%$, respectively (Bastos et al., 1996).

For the $D$. nitens collected from equines, the results for the feed conversion rate were corroborated by those obtained for other tick species, including other members of the ixodid genus for which authors report a feed conversion rate of approximately $50 \%$ (Bechara et al., 1995; Borges et al., 2001; Labruna et al., 2000; Olegário et al., 2011).

With rabbits as a host, Serra Freire and Miziara (1989) describe the parasitic phase of $D$. nitens as ranging between 23 and 42 days, whereas Drummond et al. (1969) reported an engorgement period 
Table 3

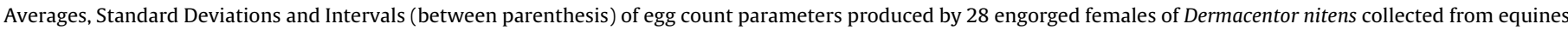
in Campo Grande, MS, Brazil.

\begin{tabular}{|c|c|c|c|}
\hline Tick species & $\begin{array}{l}\text { Average weight for } \\
\text { egg mass }(\mathrm{mg})\end{array}$ & $\begin{array}{l}\text { Total number of } \\
\text { eggs }\end{array}$ & $\begin{array}{l}\text { Number of eggs per } \\
\text { gram }\end{array}$ \\
\hline Dermacentor nitens & $\begin{array}{l}143.5 \pm 28.9 \\
(67.0-197.6)\end{array}$ & $\begin{array}{l}2628.8 \pm 483.8 \\
(1458.0-3565.0)\end{array}$ & $\begin{array}{l}18422.4 \pm 1011.4 \\
(16639.1-21761.1)\end{array}$ \\
\hline
\end{tabular}

of 40.3 days for these ticks, which diverged from the present study in which the average engorgement period was 27.6 days.

According to Serra Freire and Miziara (1989), D. nitens larval parasitic period on rabbits was between three and six days after attachment, which was different from that found in this study (average period of 7.4 days). These authors noted a period from seven to eight days for the nymph parasitic period, which in the present study, was nine days.

In Drummond et al. (1969), the engorged female weight when infesting rabbits was $76 \mathrm{mg}$, which is less than the weight of $108.4 \mathrm{mg}$ recorded in this study. Despite the success of $D$. nitens parasitism on rabbits reported by Serra Freire and Miziara (1989), these authors did not evaluate the engorged female weight after detachment.

The feed conversion rate (30\%) obtained in this study with rabbit-fed engorged females was significantly lower than the value found for equine-fed engorged females. This reduction in feed conversion rate might be due to the low weight of the engorged females collected from rabbits (Borges et al., 2001; Santos and Furlong, 2002). Similar values are described by Olegário et al. (2011) in an evaluation of $A$. parvum parasitism on different hosts; for goats (Capra hircus), the feed conversion rate is low (35.1\%) when compared with engorged females collected from other animals.

According to Drummond et al. (1969), the reproductive capacity of each $D$. nitens rabbit-fed engorged female was 376 eggs. However, in the present study, the values were higher than those obtained by these authors, with an average of 563.9 eggs per engorged female.

Regarding bovines, although noted as a natural host for this parasite, the density of infestations is always low (Borges and Silva, 1994; Rocha, 1985). According to Borges and Silva (1994), the low number of $D$. nitens on naturally infested bovines shows that they are no preferred hosts of this tick species, and these authors suggest that such parasitism is accidental. The data obtained for cows in this study corroborated the data of those authors and verified that bovines are not competent hosts for this tick species when they are artificially infested.

Although parasitism was successful on guinea pigs under laboratory conditions, Drummond et al. (1969) reported an engorgement period of 35.4 days and an engorged female weight of $192 \mathrm{mg}$. In the present study, no engorged female was recovered from these animals. A hypothesis for the failure of $D$. nitens parasitism on guinea pigs might involve the development of resistance to ticks. This is suggested because of the long time that the ticks are fixed to the host and also because this animal is not the natural host of these ticks, as described by Szabó et al. (1995), where in successive infestations of guinea pigs with $R$. sanguineus it was demonstrated the capacity of guinea pigs to develop resistance to ticks.

Regarding the nonparasitic phase of $D$. nitens, Drummond et al. (1969) reported that, under controlled temperature and humidity, for ticks fed on equines, guinea pigs and rabbits, the pre-oviposition periods were 4,3 and 3.8 days, with incubation periods of 21.1, 20 and 20.4 days, respectively.

According to Borges (1991), in a study also performed under laboratory conditions and evaluating the same parameters for ticks fed on equines, the pre-oviposition and incubation periods were 4.5 and 23 days, respectively. Guimarães da Silva et al. (1997) found that $D$. nitens engorged females, when exposed to a constant temperature of $26^{\circ} \mathrm{C}$ and 95\% humidity, had a pre-oviposition period of 3.9 days and incubation period of 26-27 days. At an identical temperature, but with a 70\% humidity index, the pre-oviposition period was 4.5 days and the incubation period was 26-27 days, which showed that a difference in humidity influenced the preoviposition period but not that of incubation.

At a constant humidity of $80 \%$ but with variable temperatures of $18^{\circ} \mathrm{C}, 27^{\circ} \mathrm{C}$ and $32^{\circ} \mathrm{C}$, the pre-oviposition periods were $13.9,4.3$ and 3.5 days, respectively, and the incubation periods were 88.7, 21.8 and 18.4 days, respectively (Bastos et al., 1996). In this study, under controlled conditions $\left(28^{\circ} \mathrm{C}\right.$ and $80 \%$ humidity), the pre-oviposition and incubation periods were 4.6 and 25.7 days for equine-fed ticks and 4.2 and 30.7 days for rabbit-fed ticks, respectively.

In the southeast region of Brazil, Labruna et al. (1997) evaluated the egg weight from six species of Ixodidae in the country, including $D$. nitens. By counting and weighing 100 eggs, these authors estimated that $1 \mathrm{~g}$ of $D$. nitens eggs had $18,181.81$ units, which is a value close to the 18,422.4 eggs per gram found in this study. According to Labruna et al. (1997), for the same tick species, differences in the number of eggs can be explained by natural differences among strains from different geographical areas or by the variability in egg size of engorged females.

With the exception of rabbits and horses, all other animal species used in this study were not competent hosts for $D$. nitens based on their inability to produce engorged females. The results showed that rabbits can be an alternate host to maintain this tick species in laboratory, although engorged female weight and egg production were less than those from engorged females fed on horses. Furthermore, the parasitic phase was longer for rabbit-fed ticks than for equine-fed ticks.

\section{Conflict of interests}

The authors declare to have no conflict of interest.

\section{Acknowlegdments}

To the Coordenação de Aperfeiçoamento de Pessoal de Nível Superior (Capes), Conselho Nacional de Desenvolvimento Científico e Tecnológico (CNPq), Fundação de Apoio ao Desenvolvimento do Ensino, Ciência e Tecnologia do Estado de Mato Grosso do Sul (Fundect, MS)-Governo do Estado de Mato Grosso do Sul and Embrapa Gado de Corte.

\section{References}

Bastos, K.M.S., Daemon, E., Faccini, J.L.H. Cunha, D.W., 1996. Efeitos de diferentes temperaturas sobre a fase não parasitária de Dermacentor (Anocentor) nitens (Neumann, 1897) (Acari: Ixodidae) em condições de laboratório. Rev. Bras. Parasitol. Vet. 5, 29-32.

Bechara, G.H., Szabó, M.P.J., Ferreira, B.R., Garcia, M.V., 1995. Rhipicephalus sanguineus ticks in Brazil: feeding and reproductive aspects under laboratorial conditions. Rev. Bras. Parasitol. Vet. 4, 61-66.

Bermudez, S.E., Eremeeva, M.L., Karpathy, S.E., Samudio, F., Zambrano, M.L. Zaldivar, Y., Motta, J.A., Dasch, G.A., 2009. Detection and identification of rickettsial agents in ticks from domestic mammals in eastern Panama. J. Med. Entomol. 46, 856-861. 
Bonnet, S., Liu, X.Y., 2012. Laboratory artificial infection of hard ticks: a tool for the analysis of tick-borne pathogen transmission. Acarol 52, 453-464.

Borges, L.M.F., Leite, R.C., 1993. Comparação entre as populações auriculares e nasais de Dermacentor nitens (Neumann, 1897) oriundas de equinos de Minas Gerais e Bahia, Brasil. Rev. Bras. Parasitol. Vet. 2, 109-110.

Borges, L.M.F., Silva, C.R.F., 1994. Ixodídeos parasitos de bovinos e equinos da microrregião de Goiânia, Goiás. Rev. Pat. Trop. 23, 69-74.

Borges, L.M.F., Oliveira, P.R., Ribeiro, M.F.B., 1999. Seasonal dynamics of the free-living phase of Anocentor nitens at Pedro Leopoldo, Minas Gerais, Brazil. Vet. Parasitol. 87, 73-81.

Borges, L.M.F., Oliveira, P.R., Ribeiro, M.F.B., 2000. Seasonal dynamics of Anocentor nitens on horses in Brazil. Vet. Parasitol. 89, 165-171.

Borges, L.M.F., Carneiro, J.R., Gomes, A.G., Moreira, P.C., 2001. Influência do peso inicial e da estação do ano na conversão em ovos de fêmeas de Boophilus microplus (Acari: Ixodidae). Ci. Anim. Bras. 2, 127-131.

Borges, L.M.F., Oliveira, P.R., Lisboa, C.L.M., Ribeiro, M.F.B., 2002. Horse resistance to natural infestations of Anocentor nitens and Amblyomma cajennense (Acari: Ixodidae). Vet. Parasitol. 104, 265-273.

Borges, L.M.F., 1991. Aspectos biológicos e de sensibilidade a acaricida do Dermacentor nitens (Neumann, 1897) em equinos e muares de alguns municípios de Minas Gerais e de Guanambi, Bahia. Dissertação de Mestrado. $57 p$.

Drummond, R.O., Whetstone, T.M., Ernst, S.E., Gladney, W.J., 1969. Laboratory study of Anocentor nitens (Neumann) (Acarina: Ixodidae), the tropical horse tick. J. Med. Ent. 6, 150-154.

Ferreira, C.G.T., Bezerra, A.C.D.S., Filgueira, K.D., Fonseca, Z.A.A.S., Ahid, S.M.M., 2009. Levantamento de ectoparasitas de cães e gatos provenientes do município de Mossoró, Rio Grande do Norte, Brasil. Pub. Vet. 3, 1-8.

Gonçalves, D.D., Carreira, T., Nunes, M., Benitez, A., Lopes-Mori, F.M.R., Vidotto, O., Freitas, J.C., Vieira, M.L., 2013. First record of Borrelia burgdorferi B31 strain in Dermacentor nitens ticks in the northern region of Parana (Brazil). Braz. J. Microbiol. 44, 883-887.

Guimarães da Silva, C.L., Santos, A.C.G., Cunha, D.W., Daemon, E., Faccini, J.L.H., 1997. Efeito de diferentes teores de umidade sobre a biologia da fase de vida livre de Anocentor nitens (Neumann) Schulze, 1937 (Acari: Idodidae). Rev. Bras. Parasitol. Vet. 6, 29-32.

Labruna, M.B., Amaku, M., 2006. Rhythm of engorgement and detachment of Anocentor nitens females feeding on horses. Vet. Parasitol. 137, 316-332.

Labruna, M.B., Leite, R.C., Oliveira, P.R., 1997. Study of the weight of eggs from six ixodid species from Brazil. Mem. Inst. Oswaldo Cruz. 92, 205-207.

Labruna, M.B., Kerber, C.E., Ferreira, F., Faccini, J.L.H., De Waal, D.T., Gennari, S.M., 2001. Risk factors to tick infestations and their occurrence on horses in the state of São Paulo. Brazil. Vet. Parasitol. 97, 1-14.

Labruna, M.B., Kasai, N., Ferreira, F., Faccini, J.L.H., Gennari, S.M., 2002. Seasonal dynamics of ticks (Acari Ixodidae) on horses in the state of São Paulo. Brazil Vet. Parasitol. 105, 65-77.
Labruna, M.B., Leite, R.C., Faccini, J.L.H., Ferreira, F., 2000. Life cycle of the tick Haemaphysalis leporis-palustris (Acari: Ixodidae) under laboratory conditions. Exp. Appl. Acarol. 24, 683-694.

Martins, T.F., Teixeira, R.H.F., Labruna, M.B., 2015. Ocorrência de carrapatos em animais silvestres recebidos e atendidos pelo Parque Zoológico Municipal Quinzinho de Barros, Sorocaba, São Paulo, Brasil. Braz. J. Vet. Res. Anim. Sci. 52 319-324.

Meng, H., Xu, S., Yu, Z., Liu, Z., Liu, J., Yang, X., Liu, J., 2014. The life cycle and occurrence of Haemaphysalis concinna (Acari: Ixodidae) under field conditions. Ticks Tick Borne Dis. 5, 887-891.

Nava, S., Mangold, A.J., Mastropaolo, M., Venzal, J.M., Fracassi, N., Guglielmone, A.A., 2011. Seasonal dynamics and hosts of Amblyomma triste (Acari: Ixodidae) in Argentina. Vet. Parasitol. 181, 301-308.

Olegário, M.M.M., Gerardi, M., Tsuruta, S.A., Szabó, M.P.J., 2011. Life cycle of the tick Amblyomma parvum Aragão, 1908 (Acari: Ixodidae) and suitability of domestic hosts under laboratory conditions. Vet. Parasitol. 179, 203-208.

Oliveira, G.P., Costa, R.P., Mello, R.P., Meneguelli, C.A., 1974. Estudo ecológico da fase não parasítica do Boophilus microplus (Canestrini, 1887) (Acarina, Ixodidae) no estado do Rio de Janeiro. Arq. Univ. Fed. Rur. 4, 1-10.

Roby, T.O., Anthony, D.W., 1963. Transmission of equine piroplasmosis by Dermacentor nitens Neumann. J. Am. Vet. Med. Assoc. 142, 768-769.

Rocha, J.M., 1985. Identificação e incidência de ixodídeos no município de Garanhuns-PE. Dissertação Mestado, 53p.

Sanavria, A., Prata, M.C.A., 1996. Ensaio metodológico para o estudo do ciclo biológico do Anocentor nitens (Neumann, 1897) (Acari: Ixodidae) em equinos experimentalmente infestados. Rev. Bras. Parasitol. Vet. 5, 91-93.

Santos, A.P., Furlong, J., 2002. Competição intraespecífica em Boophilus microplus Cienc. Rural 32, 1033-1038.

Serra Freire, N.M., Miziara, S.R., 1989. Influência do hospedeiro no ciclo e comprovação do ciclo heteróxeno de Anocentor nitens (Neumann, 1897). Mem. Inst. Oswaldo Cruz 84, 213-218.

Szabó, M.P.J., Mukai, L.S., Rosa, P.C.S., Bechara, G.H., 1995. Differences in the acquired resistance of dogs, hamsters and guinea pigs to repeated infestations with adult ticks Rhipicephalus sanguineus (Acari: ixodidae). Braz. J. Vet. Res. Anim. Sci. 32, 43-50.

Tarragona, E.L., Mangold, A.J., Mastropaolo, M., Guglielmone, A.A., Nava, S., 2015. Ecology and genetic variation of Amblyomma tonelliae in Argentina. Med. Vet. Entomol. 29, 297-304.

Yu, Z., Zheng, H., Chen, Z., Zheng, B., Ma, H., Liu, J., 2010. The life cycle and biological characteristics of Dermacentor silvarum Olenev (Acari: Ixodidae) under field conditions. Vet. Parasitol. 168, 323-328. 